\title{
Mutation in the CX3C Motif of G Protein Disrupts Its Interaction with Heparan Sulfate: A Calorimetric, Spectroscopic, and Molecular Docking Study
}

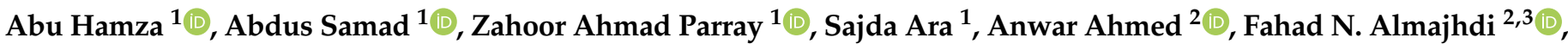 \\ Tajamul Hussain ${ }^{2}(\mathbb{D}$, Asimul Islam $1, * \mathbb{D}$ and Shama Parveen $1, * \mathbb{D}$ \\ 1 Centre for Interdisciplinary Research in Basic Sciences, Jamia Millia Islamia, New Delhi 110025, India; \\ abuhamza830@gmail.com (A.H.); a.samad0195@gmail.com (A.S.); zaparray@gmail.com (Z.A.P.); \\ sajdaarabiotech.131@gmail.com (S.A.) \\ 2 Center of Excellence in Biotechnology Research, College of Science, King Saud University, \\ Riyadh 11451, Saudi Arabia; anahmed@ksu.edu.sa (A.A.); majhdi@ksu.edu.sa (F.N.A.); thussain@ksu.edu.sa (T.H.) \\ 3 Department of Botany \& Microbiology, College of Science, King Saud University, Riyadh 11451, Saudi Arabia \\ * Correspondence: aislam@jmi.ac.in (A.I.); sparveen2@jmi.ac.in or shamp25@yahoo.com (S.P.)
}

check for updates

Citation: Hamza, A.; Samad, A.; Parray, Z.A.; Ara, S.; Ahmed, A.; Almajhdi, F.N.; Hussain, T.; Islam, A.; Parveen, S. Mutation in the CX3C Motif of G Protein Disrupts Its Interaction with Heparan Sulfate: A Calorimetric, Spectroscopic, and Molecular Docking Study. Int. J. Mol. Sci. 2022, 23, 1950. https://doi.org/ $10.3390 /$ ijms 23041950

Academic Editors: Chiara Schiraldi, Donatella Cimini, Annalisa La Gatta and Daniela Montesarchio

Received: 16 December 2021

Accepted: 28 January 2022

Published: 9 February 2022

Publisher's Note: MDPI stays neutral with regard to jurisdictional claims in published maps and institutional affiliations.

Copyright: (C) 2022 by the authors. Licensee MDPI, Basel, Switzerland. This article is an open access article distributed under the terms and conditions of the Creative Commons Attribution (CC BY) license (https:// creativecommons.org/licenses/by/ $4.0 /)$.

\begin{abstract}
Respiratory syncytial virus (RSV) is the leading cause of lower respiratory tract infection in children and infants. To date, there is no effective vaccine available against RSV. Heparan sulfate is a type of glycosaminoglycan that aids in the attachment of the RSV to the host cell membrane via the $G$ protein. In the present study, the effect of amino acid substitution on the structure and stability of the ectodomain $G$ protein was studied. Further, it was investigated whether mutation (K117A) in the CX3C motif of $G$ protein alters the binding with heparan sulfate. The point mutation significantly affects the conformational stability of the $G$ protein. The mutant protein showed a low binding affinity with heparan sulfate as compared to the wild-type G protein, as determined by fluorescence quenching, isothermal titration calorimetry (ITC), and molecular docking studies. The low binding affinity and decreased stability suggested that this mutation may play an important role in prevention of attachment of virion to the host cell receptors. Collectively, this investigation suggests that mutation in the $\mathrm{CX} 3 \mathrm{C}$ motif of $\mathrm{G}$ protein may likely improve the efficacy and safety of the RSV vaccine.
\end{abstract}

Keywords: RSV; G protein; CX3C motif; glycosaminoglycan; heparan sulfate; fluorescence binding; isothermal titration calorimetry; molecular docking

\section{Introduction}

Respiratory syncytial virus (RSV), which belongs to the family Pneumoviridae and genus Orthopneumovirus, is the leading cause of acute lower respiratory infection in the elderly and children, especially those less than 2 years of age [1-3]. RSV is the main cause for the hospitalization of approximately 20 per 1000 infants, which leads to the deaths of around 6.6 per 1000 infants of less than 12 months [4]. A report articulated that globally, around 48,000 to 74,000 deaths occur every year due to RSV, mostly in the pediatric population [5]. Currently, no approved vaccine is available to prevent RSV infection. The only defensive measure is the injection of palivizumab, a monoclonal antibody specific to the viral fusion (F) glycoprotein [6]. The two envelope glycoproteins of RSV, G and F, are responsible for viral attachment and fusion, respectively. The G protein of RSV is a type II transmembrane glycoprotein and acts as an important target of host immune cell response. The size of the $G$ protein varies in circulating strains from $282-321$ aa. The $G$ protein comprises three main domains: the cytoplasmic domain of amino acids $1-37$, the transmembrane domain of amino acids 38-66, and the ectodomain region of amino acids 67-312. The ectodomain part of the $G$ protein has an unglycosylated central conserved region. The two hypervariable 
mucin-like domains also present flanking to the central conserved region [7-9]. The central region contains 13 amino acid central conserved domains (CCDs) of amino acids 164-176 that are highly conserved in all strains of RSV [10-12]. The four cysteine residues at the amino acid positions 173, 176, 182, and 186 form the cysteine noose, which is bound together via two disulfide bonds between Cys173-Cys186 and Cys176-Cys182 [13]. This region serves as a putative receptor-binding site and is slightly hydrophobic [11]. Two hypervariable regions are present flanking the cysteine regions that are similar to the amino acid composition of mucin, a protein secreted by the epithelial cell. It has a high content of amino acids such as serine, threonine, and proline, which serve as hotspots for mutations [14]. The mucins are host glycoproteins that act as a protective barrier on gastrointestinal, respiratory, and reproductive tracts. The third (Cys182) and fourth cysteine (Cys186) of the central conserved domain form the CX3C motif of amino acids 182-186. The CX3C motif of the G protein aids in the attachment of RSV to the vulnerable human airway epithelial (HAE) cells with the interaction of the chemokine receptor (CX3CR1) [13,15-17]. The $\mathrm{G}$ protein shows structural similarities with $\mathrm{CX} 3 \mathrm{C}$ chemokine fractalkine and induces leukocyte chemotaxis in the in vitro condition [18]. Downstream from the cystine noose, the positively charged heparin-binding domain (HBD) is present in amino acids 184-198 of the $\mathrm{G}$ proteins. The HBD helps in the attachment of the RSV through cell surface glycosaminoglycans (GAGs) $[19,20]$. The GAGs (heparin and heparin sulfate) present on the surface of mammalian cells act as a receptor for RSV in different cell lines (such as Hep-2 cells). Previous studies showed that the basic amino acids of the HBD of the G protein helps in the attachment of RSV through negatively charged heparan sulfate present on the host cells [16,19]. Another study also reported that heparan sulfate, and to a lesser amount chondritin-4-sulfate, was also found to be involved in attachment of RSV to the membrane of host cell [21].

RSV infects many cell types, but mainly infects respiratory tract epithelial cells, which results in the expression of chemokine and cytokines, adaptive and innate immune responses, and pulmonary inflammation, which control viral replication and infection [22-24]. The monoclonal antibodies (mAbs), which targeted the G protein, neutralized the RSV infection in HAE cells and diminished the viral load in animal models [25,26]. The anti-G mAbs reduced mucus production, proinflammatory cytokines, and pulmonary inflammation, and reinstated the Th1/Th2 cytokine balance $[27,28]$. The mAbs targeting the CCD of the $G$ protein were protective in prophylactic and post infection animal models $[27,29]$.

The $F$ and $G$ glycoproteins both are targeted by the humoral immune response against RSV [30]. The human mAbs 3G12 and 3D3, which bind with the CCD, have been shown to strongly neutralize both subtypes of RSV. These antibodies bind to the G protein of RSV with high affinity, and protected mice from RSV infection [31,32]. Moreover, the CCD of the $G$ protein has been shown to elicit a long-lasting and defensive antibody response in mice $[33,34]$. This type of study is directed to the isolation of a murine antibody (131-2G), which binds to the CCD and blocks the interaction of CX3CR1 with G protein, thus inhibiting viral attachment [18]. Previous studies showed that the T-cell epitope, which is found in amino acids 184-203 in the G protein, is involved in protective immunity against the RSV infection and induction of T-cell response and eosinophilia $[35,36]$. Thus, the CX3C motif and the CCD of the G protein are very important in designing an RSV vaccine. The immunization of mice with an RSV G protein or polypeptide having a CCD induces a protective antibody response [37,38], and likewise for the CX3C motif [39,40]. Recently, Bergeron and colleagues reported that a vaccine targeting the RSV G protein encoded with a central conserved domain induced antibodies, blocking the CX3C-CX3CR1 [41]. Since binding of the $\mathrm{G}$ protein to CX3CR1 through the CX3C motif is important to cause RSV infection; mutations in this motif might prevent disease. Previously, it was reported that mutating the $\mathrm{CX} 3 \mathrm{C}$ motif in the $\mathrm{G}$ protein should improve the more effective and safer vaccine against RSV [37].

In the study presented here, we describe the structural and binding studies of a mutant $\mathrm{G}$ protein. We cloned and expressed the mutant ectodomain $\mathrm{G}$ protein in the bacterial 
system. Protein was purified from the bacterial cell pellet from the solubilized IBs using Ni-NTA affinity chromatography. We monitored changes in the tertiary structure in a wide range of $\mathrm{pH}$, using fluorescence spectroscopy. Further, $\mathrm{GdmCl}$ - and urea-induced denaturation studies were performed to monitor the structural change and to measure stability of the protein. Isothermal titration calorimetry (ITC), fluorescence quenching, absorbance spectroscopy, and in silico approaches were exploited to determine the interaction of the mutant $G$ protein with the heparan sulfate.

\section{Results and Discussion}

\subsection{Strategy Used for the Generation of Mutation in the G Protein}

Previous studies showed that the CX3C chemokine motif present in the central conserved region of $G$ protein bound with the CX3CR1 receptor present on HAE cells [16]. The alterations of amino acid in this region are likely to affect the binding of the virion to the host cell receptors, therefore preventing RSV infection [37]. Based on this idea and reported studies, we mutated the positively charged lysine $(\mathrm{K})$ amino acid residue to the neutrally charged alanine (A) in the $\mathrm{CX} 3 \mathrm{C}$ motif. This substitutional mutation changed the $\mathrm{CX} 3 \mathrm{C}$ motif $\left(\mathrm{CK}^{183} \mathrm{SIC}\right.$ to $\left.\mathrm{CA}^{183} \mathrm{SIC}\right)$ with respect to the full-length $\mathrm{G}$ protein (Figure $\left.1 \mathrm{~A}\right)$. Since we used the ectodomain region of the $G$ protein for the present study, the mutated $C X 3 C$ motif position was $\mathrm{CK}^{117}$ SIC to $\mathrm{CA}^{117} \mathrm{SIC}$ (Figure $1 \mathrm{~B}$ ). We mutated the positively charged amino acid to the neutral amino acid to disrupt the interaction of the $G$ protein with the host cell membrane. The previous study reported that the positively charged amino acids of the $G$ protein interacted with negatively charged heparin/heparin sulfate molecules present on the host cell receptors. Therefore, we chose to mutate the lysine residues to alanine in the $\mathrm{CX} 3 \mathrm{C}$ motif of the $\mathrm{G}$ protein.

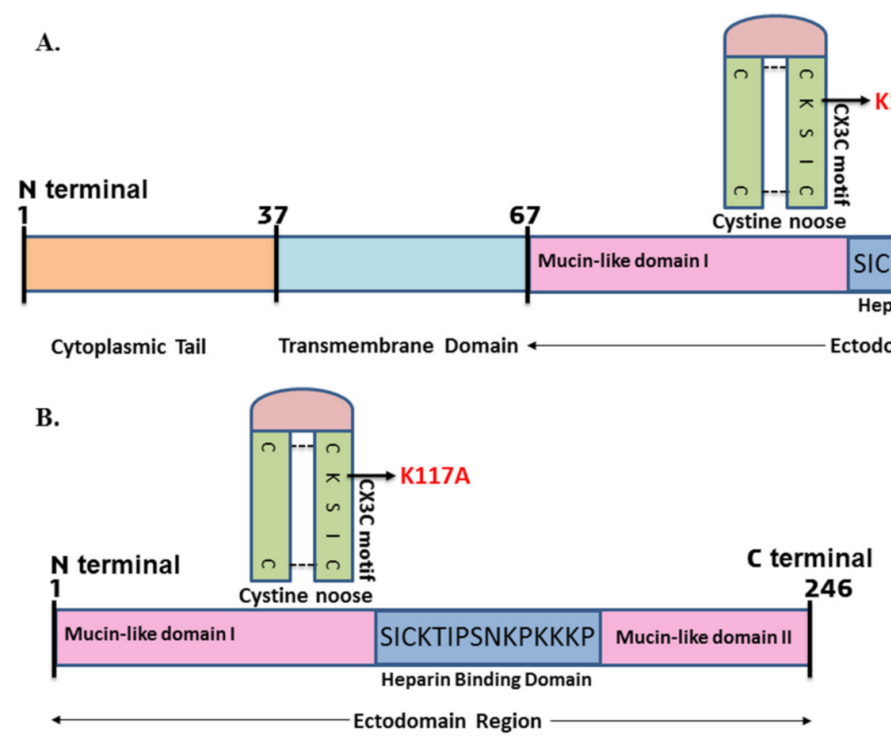

Figure 1. (A) Schematic representation of RSV G protein showing mutation in the CX3C motif of $\mathrm{G}$ protein $(\mathrm{K} 183 \mathrm{~A})$ with respect to full length. (B) Considering the ectodomain region of the $\mathrm{G}$ protein, the mutated amino acid position was K117A.

\subsection{Cloning, Expression, and Purification of the Mutant G Protein}

The plasmid of the mutant $G$ protein gene was transformed into the $E$. coli host cell strain of BL21 (DE3), and the isolated plasmid was analyzed using agarose gel electrophoresis (Figure 2A). A culture with induction of $0.5 \mathrm{mM}$ IPTG was grown at $30^{\circ} \mathrm{C}$ for $12 \mathrm{~h}$ for maximum protein expression. The inclusion bodies (IBs) were prepared from the harvested bacterial cell by sonication and centrifugation using lysis buffer and autoclaved Milli- $Q$ water. Washing steps were used to eliminate the host protein, proteases, DNA, endotoxin, and nonspecific proteins [42]. The IBs were solubilized in CAPS buffer containing $N$-lauroylsarcosine. After solubilization and centrifugation, the soup was loaded on the 
Ni-NTA column, eluted with an increasing concentration of imidazole, and analyzed by SDS-PAGE. The desired protein fractions were eluted out with 100-200 mM of imidazole concentration. Further, the desired protein was dialyzed $4-5$ times at $4{ }^{\circ} \mathrm{C}$ to refold the protein into the correct native conformation spontaneously. After dialysis, the protein solution was centrifuged and filtered using a $0.22 \mu \mathrm{m}$ syringe filter to remove any precipitate formed during dialysis. The dialyzed protein was analyzed through SDS-PAGE, which indicated the purity of the protein (Figure 2B).

A.

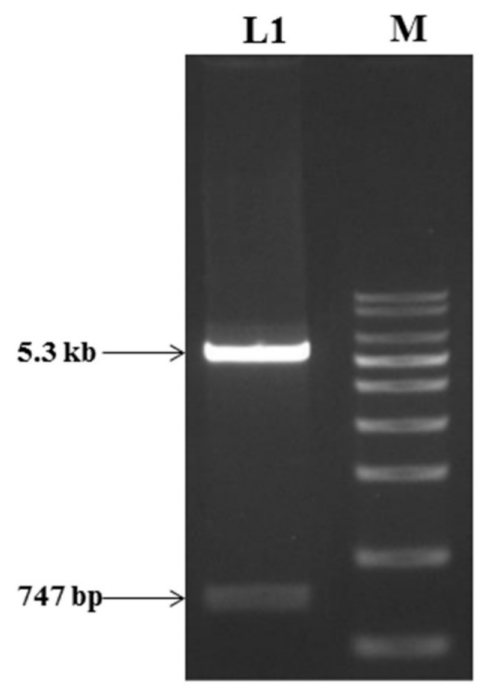

B.

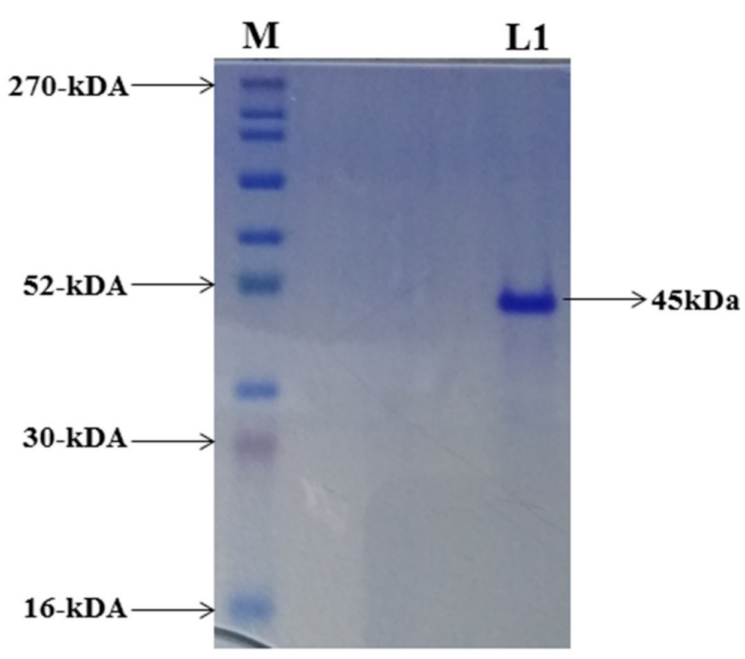

Figure 2. (A) Lane 1 showing the digested products of pET-28a vector and insert of mutant $\mathrm{G}$ protein gene. Lane M is a molecular marker. (B) SDS-PAGE gel photograph of purified mutant G protein.

\subsection{Structural and Conformational Stability Measurements of the Mutant G Protein}

\subsubsection{Fluorescence Measurements}

Fluorescence spectroscopy provides information about the tertiary structure of a protein due to the presence of aromatic amino acids, which are highly sensitive to the local environment. The change in the emission spectra of the mutant $\mathrm{G}$ protein at different $\mathrm{pH}$ values is shown in Figure 3. A considerable decrease in emission intensity was noticed as we moved from physiological $\mathrm{pH}$ to acidic $\mathrm{pH}$ values $(\mathrm{pH} 8.0-2.0)$. The decrease in emission intensity may have been due to the quenching mechanism, the protonation of water molecules, or acidic amino acids present in the surrounding intrinsic fluorophores. Similarly, a considerable decrease in emission intensity was noticed as we moved from physiological $\mathrm{pH}$ to basic $\mathrm{pH}$ values ( $\mathrm{pH}$ 8.0-12.0), which might have been due to the deprotonation of basic amino acids that surrounded the intrinsic fluorophore and caused fluorescence quenching. The protonation and deprotonation changed the charge in the local milieu by altering electrostatic interactions and internal salt bridges that were present in native protein [43]. The emission spectra of the protein at $\mathrm{pH} 8.0$ showed an emission maxima peak $\left(\lambda_{\max }\right)$ at $344 \mathrm{~nm}$, which is the native conformation of the protein. The plot of $\lambda_{\max }$ as a function of $\mathrm{pH}$ showed no considerable change in the $\lambda_{\max }$ of the protein from $\mathrm{pH}$ 4.0-9.0. This can be attributed to the microenvironment around the aromatic amino acid not being disturbed significantly. However, in highly acidic conditions ( $\mathrm{pH} 2.0-3.0)$ and highly basic conditions ( $\mathrm{pH}$ 10.0-12.0), a slight redshift of $2 \mathrm{~nm}$ from 344 to 346 in the $\lambda_{\max }$ was observed (inset of Figure 3). A redshift in emission maxima is indicative of the increased solvent interactions of aromatic amino acids due to the unfolding of the protein [44]. Previously, we reported that the wild-type G protein showed a redshift of $5 \mathrm{~nm}$ in the $\lambda_{\max }$ only at $\mathrm{pH} 12.0$ [45]. Finally, our fluorescence study concluded that the tertiary structure of the protein was perturbed as we moved from the physiological $\mathrm{pH}$ to 
the acidic or basic $\mathrm{pH}$ values, and changes in the $\lambda_{\max }$ were observed in highly basic and acidic $\mathrm{pH}$ conditions.

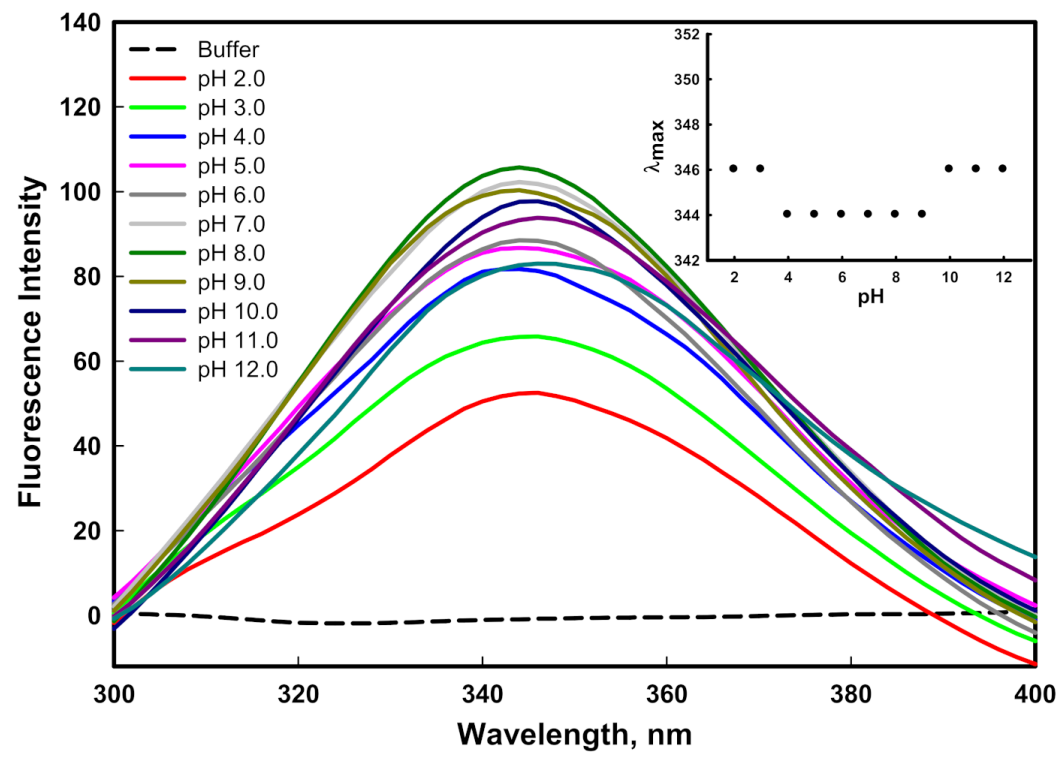

Figure 3. Fluorescence spectra of mutant $\mathrm{G}$ protein at different $\mathrm{pH}$ values ranging from 2.0-12.0 at $25{ }^{\circ} \mathrm{C}$. The inset illustrates the protein denaturation profile by monitoring changes in emission maxima $\left(\lambda_{\max }\right)$ as a function of $\mathrm{pH}$.

\subsubsection{ANS Binding Measurements}

Changes in the tertiary structure of a protein in various environmental conditions often lead to the exposure of hydrophobic patches, which are usually buried in the native form of the protein. Some proteins form an intermediate state during the process of unfolding, which is commonly known as the molten globule (MG) state [46]. ANS dye was specifically used to investigate the presence of hydrophobic clusters on the surface of the protein. ANS generally does not bind to a native protein, as hydrophobic patches are buried inside the core of the protein. ANS also does not bind to a denatured protein, as hydrophobic residues are present at large distances. The binding of ANS to the hydrophobic patches often leads to higher fluorescence intensity, which demonstrates the presence of an intermediate state, and hints at the formation of molten or premolten globule confirmations [46]. Figure 4 shows that the ANS fluorescence intensity of the protein at $\mathrm{pH} 2.0$ and 3.0 was very high in comparison to the native state of the protein $(\mathrm{pH} 8.0)$. The high fluorescence intensity and shifting of emission maxima $\left(\lambda_{\max }\right)$ toward the shorter wavelength suggested the exposure of hydrophobic patches to solvent [47]. Therefore, the non-native state of the mutant $\mathrm{G}$ protein at $\mathrm{pH} 2.0$ and 3.0 was regarded as an acid-induced molten globule like state. Similar to the mutant protein, the wild-type $G$ protein also formed the molten globule like state at highly acidic $\mathrm{pH}$ values in our previous investigation [45]; in both cases, this was attributed to the hydrophobic patches being exposed when the protein was populated at $\mathrm{pH} 2.0$ and 3.0 in the solutions. It was observed that the ANS fluorescence intensity decreased as the $\mathrm{pH}$ of the solution moved toward the basic condition (inset of Figure 4). ANS binding was prevented in physiological and alkaline conditions due to the inaccessibility of the hydrophobic cluster, because at these $\mathrm{pH}$ values, the hydrophobic patches might have been buried in the core of the protein, or present at a large distance [48]. 


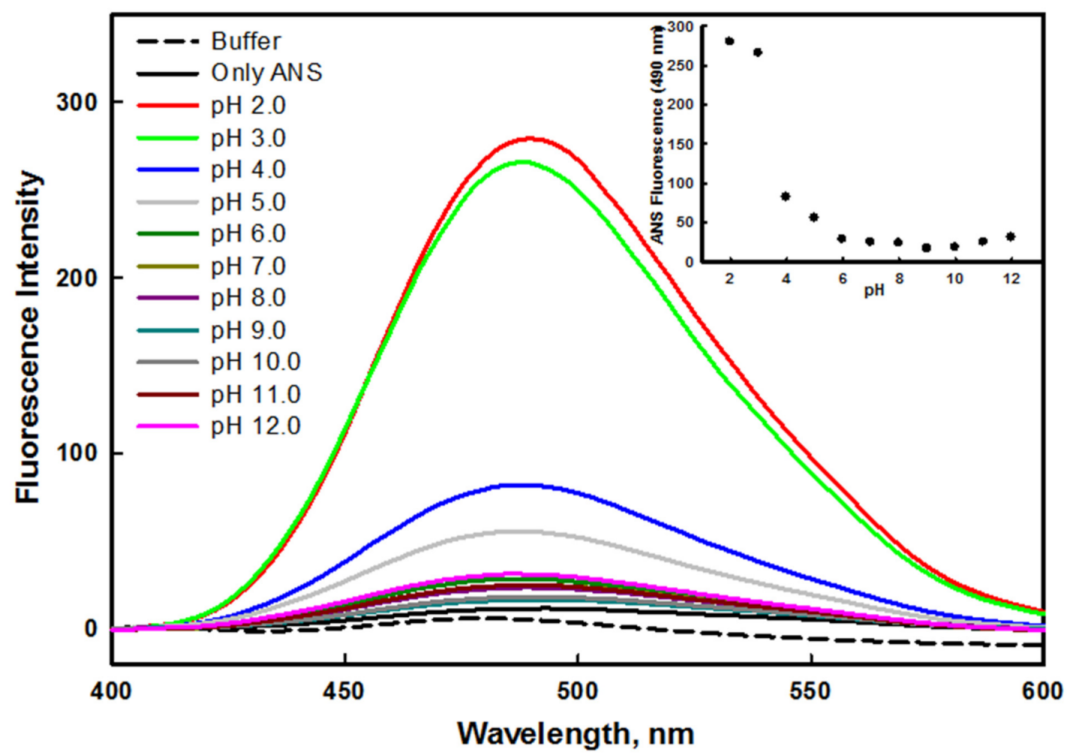

Figure 4. ANS fluorescence spectra of mutant $\mathrm{G}$ protein at different $\mathrm{pH}$ values ranging from $2.0-12.0$ at $25^{\circ} \mathrm{C}$. The inset illustrates the ANS profile of protein by observing changes in $F_{490}$ as a function of $\mathrm{pH}$.

\subsubsection{GdmCl- and Urea-Induced Denaturation}

The stability of a protein can be quantified by equilibrium unfolding measurements in the presence of urea or $\mathrm{GdmCl}[49,50]$. The aromatic amino acid of the protein, which is often fully or partially buried in the hydrophobic core of the protein, serves as an indicator of the structural integrity of the protein. The stability of the protein was measured using intrinsic tryptophan, which is an important probe. Figures 5 and 6 show the emission spectra of the mutant $\mathrm{G}$ protein with increasing concentrations of $\mathrm{GdmCl}$ and urea, respectively. We observed that the emission spectra of the protein changed as we increased the concentration of $\mathrm{GdmCl}$ and urea. As we increased the concentration of the denaturant, the fluorescence intensity decreased with the shifting of the emission maxima $\left(\lambda_{\max }\right)$ toward the higher wavelength (redshift). The spectra of the protein in the absence of a denaturant showed an emission maxima $\left(\lambda_{\max }\right)$ peak at $344 \mathrm{~nm}$; however, at a higher concentration of denaturant, the $\lambda_{\max }$ of the protein was shifted to $356 \mathrm{~nm}$. From these results, we inferred that the aromatic amino acids of the protein were shifted from nonpolar to polar environmental conditions, as the $\mathrm{GdmCl}$ and urea (denaturants) exposed the buried aromatic amino acid residues [51]. Our results also suggested that as we increased the $\mathrm{GdmCl}$ or urea concentration, unfolding of the protein occurred, which exposed the buried tryptophan residues to a more polar buffer condition. The alteration in the microenvironment of tryptophan was monitored using $F_{344}$ (fluorescence emission intensity at $344 \mathrm{~nm}$ ) as a function of $\mathrm{GdmCl}$ (inset of Figure 5) and urea (inset of Figure 6). The plots of $F_{344}$ versus [GdmCl] and [urea] showed that the denaturation process in the presence of the denaturant followed a two-state process. The denaturation transition curves were examined to obtain the value of stability parameters such as $\Delta G_{D}{ }^{0}$ (Gibbs free energy change in the absence of denaturants), $m$ (slope), and $C_{m}$ (transition midpoint of denaturation curve) by fitting the entire denaturation curve to Equation (1). The thermodynamic stability parameters of mutant $\mathrm{G}$ protein are given in Table 1.

Table 1. Thermodynamic parameters obtained from GdmCl- and urea-induced denaturation of mutant $\mathrm{G}$ protein at $\mathrm{pH} 8.0$.

\begin{tabular}{|c|c|c|c|c|c|}
\hline Probes & Denaturants & Transition & $\Delta G_{D}{ }^{0}, \mathrm{kcal} \mathrm{mol}^{-1}$ & $m, \mathrm{kcal} \mathrm{mol}^{-1} \mathbf{M}^{-1}$ & $C_{m}, \mathbf{M}$ \\
\hline \multirow{2}{*}{$F_{344}$} & $\mathrm{GdmCl}$ & $\mathrm{N} \leftrightarrow \mathrm{D}$ & $2.22 \pm 0.22$ & $1.50 \pm 0.10$ & $1.48 \pm 0.08$ \\
\hline & Urea & $\mathrm{N} \leftrightarrow \mathrm{D}$ & $2.87 \pm 0.21$ & $0.99 \pm 0.06$ & $2.90 \pm 0.13$ \\
\hline
\end{tabular}




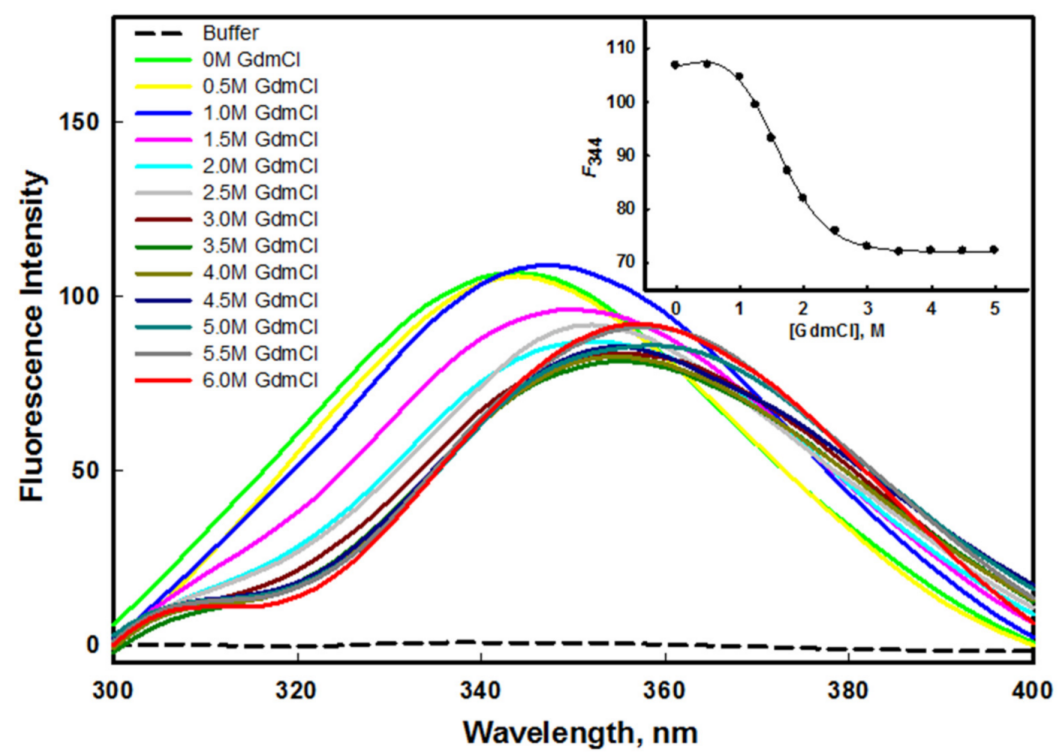

Figure 5. GdmCl-induced denaturation of mutant $\mathrm{G}$ protein at $\mathrm{pH} 8.0$ and $25^{\circ} \mathrm{C}$. The inset shows the denaturation curve of protein (plot of $F_{344}$ as a function of different concentration of $\mathrm{GdmCl}$ ).

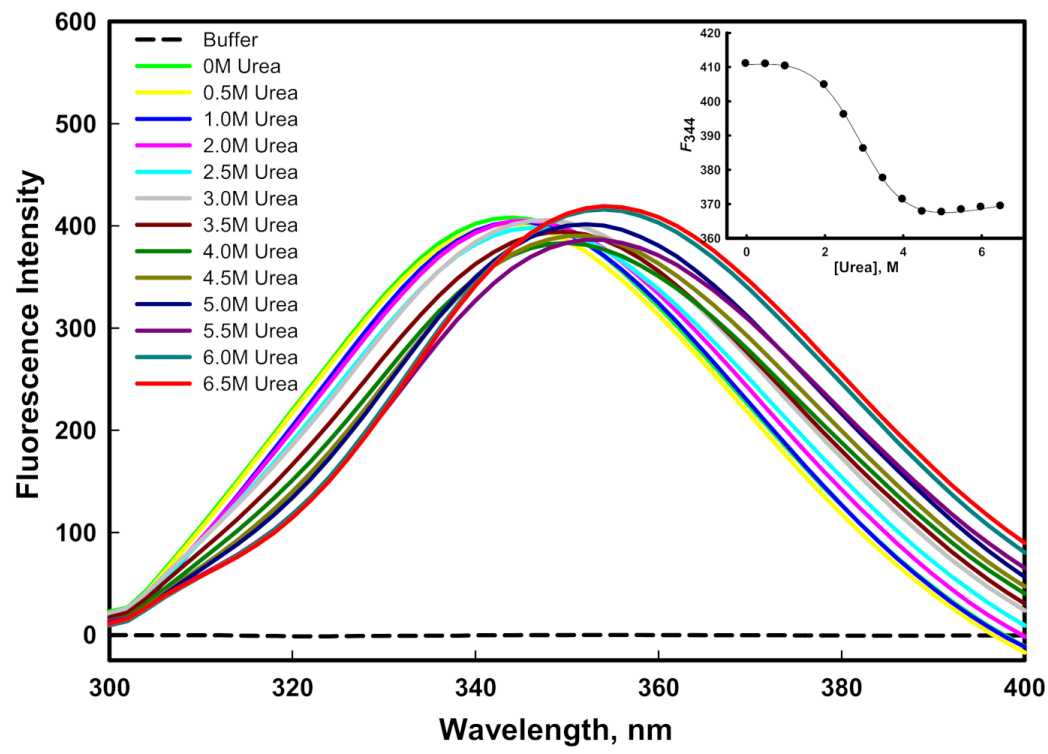

Figure 6. Urea-induced denaturation of mutant $\mathrm{G}$ protein at $\mathrm{pH} 8.0$ and $25^{\circ} \mathrm{C}$. The inset shows the denaturation curve of protein (plot of $F_{344}$ as a function of different concentration of urea).

In our previous investigation, we reported the $\mathrm{GdmCl}$ - and urea-induced denaturation of the wild-type $\mathrm{G}$ protein [45], in which we found that $\mathrm{GdmCl}$ - and urea-induced denaturation followed a two-state transition mechanism. The $\Delta G_{D}{ }^{0}$ value of the wild-type $\mathrm{G}$ protein in the presence of urea was $3.76 \pm 0.34 \mathrm{kcal} \mathrm{mol}^{-1}$; however, it was found to be $2.87 \pm 0.21 \mathrm{kcal} \mathrm{mol}^{-1}$ in the mutant $\mathrm{G}$ protein, which indicated that the wild-type $\mathrm{G}$ protein was more stable than the mutant $\mathrm{G}$ protein in the presence of urea. The $C_{m}$ value for the mutant $\mathrm{G}$ protein was found to be $2.90 \pm 0.13 \mathrm{M}$, while it was $4.42 \pm 0.16 \mathrm{M}$ in the case of the wild-type $G$ protein [45]. It is well known that urea interacts differently with hydrophobic groups than with either protein backbones or hydrophilic groups [52]. It should be noted that the unfolding process by urea arises due to the weakening of hydrophobic interactions between the polymer groups [53]. Urea denatures the protein by destabilizing the hydrophobic forces. It seemed that the mutant protein was less stable where hydrophobic forces were lower than those of the wild-type protein. On the other hand, the $\Delta G_{D}{ }^{0}$ value of the wild-type $\mathrm{G}$ protein in the presence of $\mathrm{GdmCl}$ was $2.53 \pm 0.20 \mathrm{kcal} \mathrm{mol}^{-1}$; however, it 
was found to be $2.22 \pm 0.22 \mathrm{kcal} \mathrm{mol}^{-1}$ in the mutant $\mathrm{G}$ protein, which we attributed to the wild-type $\mathrm{G}$ protein being more stable than the mutant $\mathrm{G}$ protein in the presence of $\mathrm{GdmCl}$. The $C_{m}$ values of the wild-type $(1.52 \pm 0.07 \mathrm{M})$ and mutant protein $(1.48 \pm 0.08 \mathrm{M})$ were found to be similar in the presence of $\mathrm{GdmCl}$; i.e., 1.5 $\mathrm{M}$ [45]. The unfolding transitions induced by $\mathrm{GdmCl}$ and urea are not always found to be similar; the difference in the free energy of unfolding might have been due to the ionic effect of $\mathrm{GdmCl}$ [54].

\subsection{Binding Studies of Heparan Sulfate with the Mutant G Protein}

\subsubsection{Fluorescence Binding Measurements}

Fluorescence spectroscopy is a very simple and sensitive technique to study proteinligand interactions. It is mainly used to determine the number of binding sites $(n)$, SternVolmer constant $\left(K_{s v}\right)$, binding constant $(K)$, and interaction mechanism between a protein and ligand. For binding measurements, the protein sample was excited at $280 \mathrm{~nm}$. Excitation of a protein at $280 \mathrm{~nm}$ is considered as fluorescence of tyrosine, tryptophan, and phenylalanine [55]. Figure 7A shows the emission spectra of the mutant G protein with an increasing $(0-40 \mu \mathrm{M})$ concentration of heparan sulfate (HS). The HS did not flourish alone, whereas the protein showed a peak of maxima $\left(\lambda_{\max }\right)$ at $344 \mathrm{~nm}$ in the same environment. The fluorescence intensity of the protein gradually decreased as we increased the concentration of HS, suggesting the formation of a complex between the ligand and protein. The experimental data were analyzed to calculate the $K_{s v}$ using Equation (2). Figure 7B represents the Stern-Volmer plots of protein quenching in various concentrations of heparan sulfate. The $K_{s v}$ value was obtained using Equation (2) by fitting the fluorescence intensity ratio $F_{0} / F$ for various concentrations [C] of HS. The quenching mode was further confirmed from the value of $K_{q}$ (bimolecular quenching constant) using Equation (3). The experimental data were further analyzed by using Equation (4), which showed the binding constant $(K)$ value (Figure $7 C$ ). The binding interaction parameters of HS with the mutant $\mathrm{G}$ protein are given in Table 2 .

A.

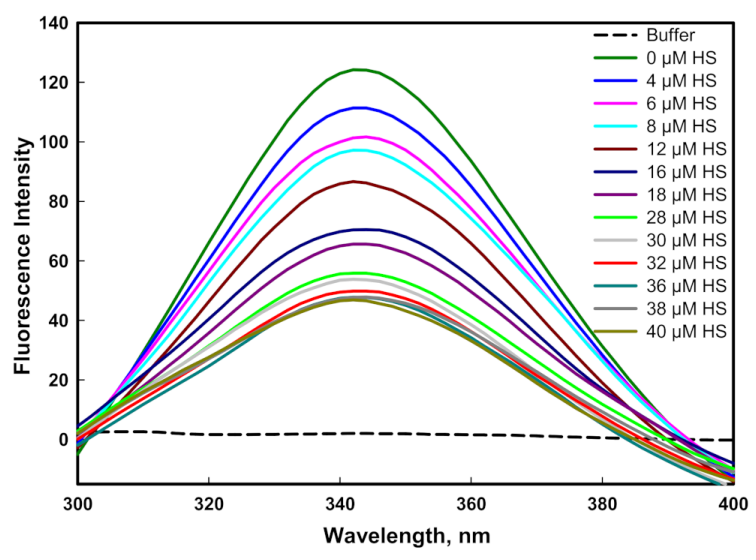

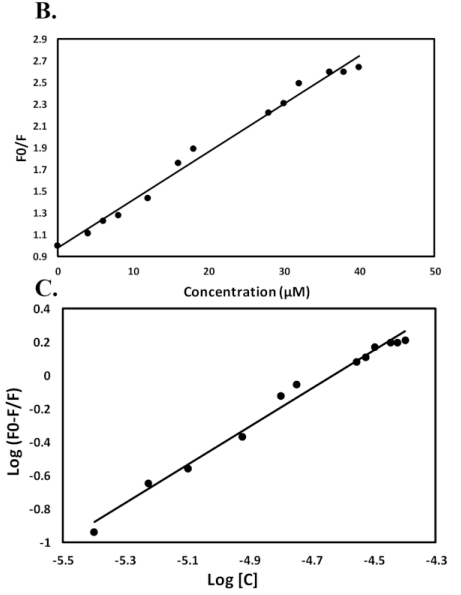

Figure 7. Fluorescence binding studies of the mutant $\mathrm{G}$ protein with heparan sulfate at $\mathrm{pH} 7.5$ and $25^{\circ} \mathrm{C}$. (A) Fluorescence spectra of mutant $\mathrm{G}$ protein with increasing concentration of heparan sulfate $(0-40 \mu \mathrm{M})$. (B) Stern-Volmer plot for quenching of protein-HS complex. (C) Modified Stern-Volmer plot obtained from titration of heparan sulfate, which is used for the calculation of binding affinity.

Table 2. Fluorescence binding parameters of the mutant $\mathrm{G}$ protein with heparan sulfate at $\mathrm{pH} 7.5$ and $25^{\circ} \mathrm{C}$.

\begin{tabular}{ccccc}
\hline $\boldsymbol{K}_{s v}\left(\mathbf{M}^{-\mathbf{1}}\right)$ & $\boldsymbol{K}_{q}\left(\mathbf{M}^{-\mathbf{1}} \mathbf{s}^{-\mathbf{1}}\right)$ & $\boldsymbol{K}\left(\mathbf{M}^{-\mathbf{1}}\right)$ & $\boldsymbol{n}$ & $\mathbf{R}^{\mathbf{2}}$ \\
\hline $4.42 \times 10^{4}$ & $1.63 \times 10^{13}$ & $2.08 \times 10^{5}$ & 1.14 & 0.98 \\
\hline
\end{tabular}


The binding constant $(K)$ value of the mutant protein with HS was found to be $2.08 \times 10^{5} \mathrm{M}^{-1}$. However, in our previous study, we observed that the binding constant value between HS and the wild-type $\mathrm{G}$ protein was $3.98 \times 10^{6} \mathrm{M}^{-1}$ [45]. From these observations, we concluded that when we substituted the lysine residue with alanine (K117A) in the $\mathrm{CX} 3 \mathrm{C}$ motif of the $\mathrm{G}$ protein, a low binding constant value was found. The low binding of the mutant $\mathrm{G}$ protein with HS was attributed to the mutation in this region disrupting the binding interactions. Moreover, the low binding might have been due to the disruption of electrostatic interactions between the positively charged amino acid (lysine) of the protein and the negatively charged group of the HS.

\subsubsection{Absorbance Binding Measurements}

In a protein, the presence of a conjugated bond system in the side chain of aromatic amino acids acts as a chromophore that absorbs UV light in the range of 240-340 nm [56]. The mutant $G$ protein contains five tyrosine residues, which showed an absorption maxima peak at $278 \mathrm{~nm}$. The alteration in the tertiary structure of the protein with the addition of HS indicated binding of the ligands to the target protein [57]. The absorption spectra of mutant protein gradually decreased as we increased the concentration of HS, suggesting the binding of the ligand with the protein (Figure 8). It was noted that the quenching stopped after the addition of $48 \mu \mathrm{M}$ of HS, which was an indication of the formation of a stable complex (inset of Figure 8). Similar to the mutant protein, the absorbance spectra of wild-type $\mathrm{G}$ protein decreased with an increasing concentration of HS, as reported in our previous investigation [45].

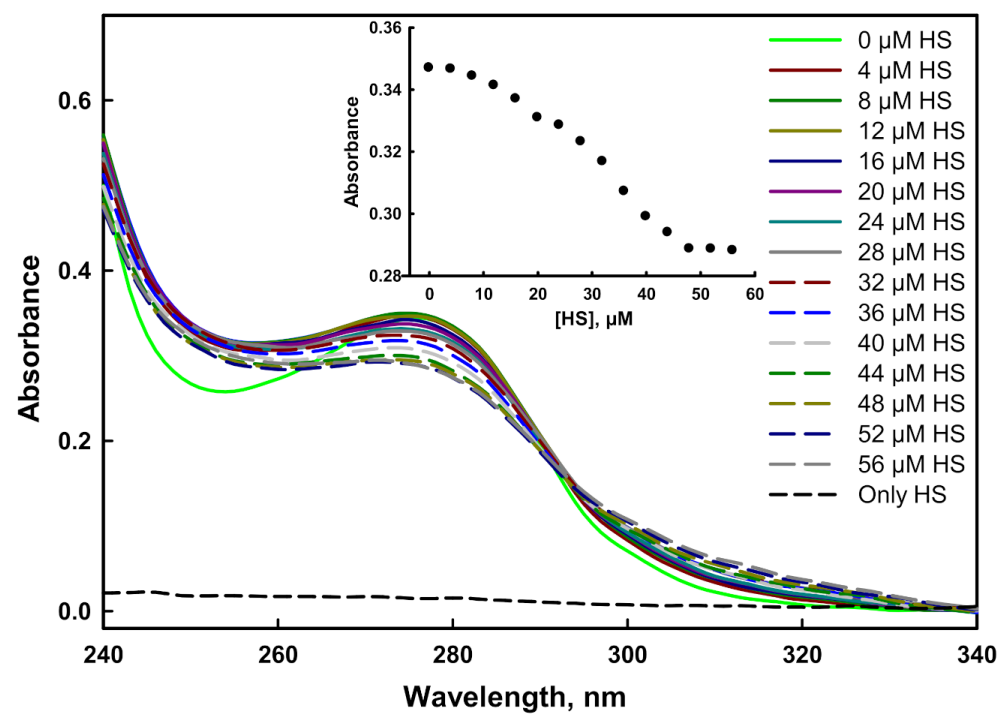

Figure 8. Absorbance binding measurements of the mutant $\mathrm{G}$ protein with heparan sulfate at $\mathrm{pH} 7.5$ and $25{ }^{\circ} \mathrm{C}$. Spectra were recorded with increasing concentrations of heparan sulfate $(0-56 \mu \mathrm{M})$.

\subsubsection{ITC Measurements}

For the binding affinity measurements of heparan sulfate with the mutant G protein, we performed isothermal titration calorimetry (ITC), which provides information about the interaction of the ligand with the protein. Figure 9 shows the thermogram of raw data in power versus time for titration of the ligand (HS) against the reaction cell that contained the mutant $\mathrm{G}$ protein. In the upper panel, each peak in the binding isotherm signifies the single injection of the HS, whereas the lower panel denotes the integration of the area under each injection peak of the heat profile, which aided in generating a differential curve. The thermodynamic binding parameters of HS with the mutant G protein are given in Table 3. 


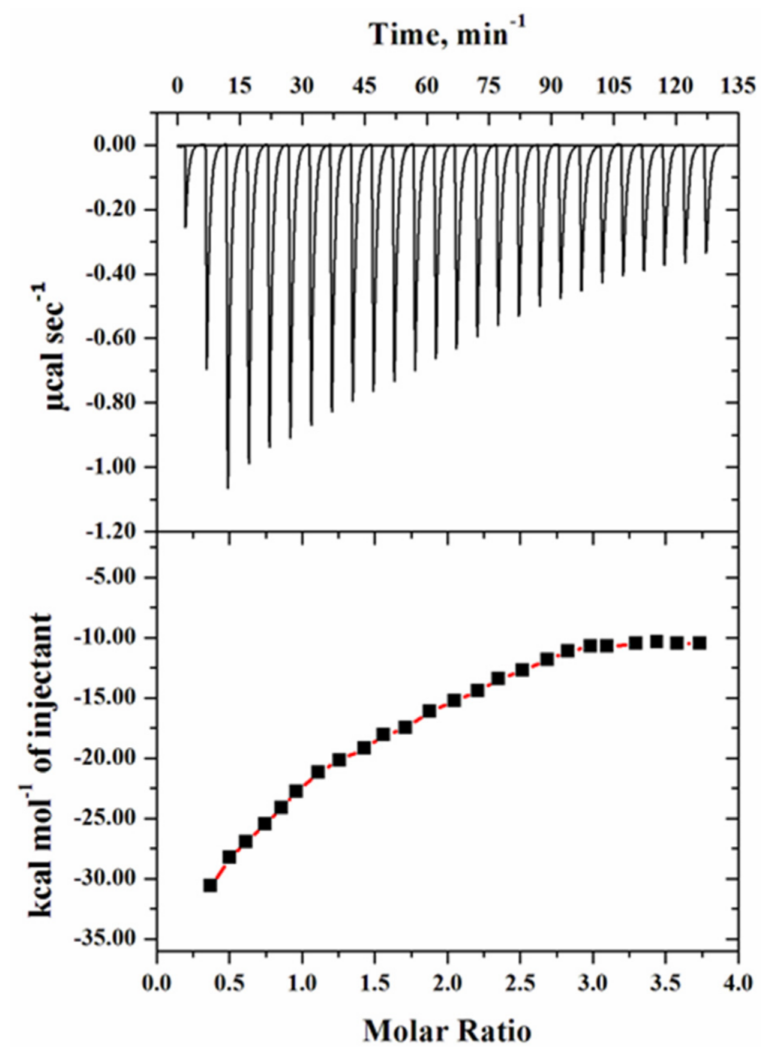

Figure 9. ITC thermogram of mutant $\mathrm{G}$ protein with $10 \mu \mathrm{M}$ protein and $200 \mu \mathrm{M}$ heparan sulfate. The thermogram of raw data in power versus time is shown in the upper panel, with each peak in the binding isotherm representing a single ligand injection. The lower panel indicates the quantity of heat emitted as a function of the mole ratio of the protein to ligand at $\mathrm{pH} 7.5$ and $25^{\circ} \mathrm{C}$.

Table 3. Binding parameters of the mutant $G$ protein with heparan sulfate by ITC measurements at $\mathrm{pH} 7.5$ and $25^{\circ} \mathrm{C}$ The data in the bracket is standard error of the given values.

\begin{tabular}{ccccc}
\hline \multicolumn{5}{c}{ Thermodynamic Binding Parameters (Units) } \\
\hline$n$ & $\begin{array}{c}\boldsymbol{K}_{\boldsymbol{a}} \\
\left(\mathbf{M}^{-\mathbf{1}}\right)\end{array}$ & $\begin{array}{c}\boldsymbol{\Delta} \boldsymbol{H}^{\mathbf{0}} \\
\left(\mathbf{c a l ~ m o l}^{-\mathbf{1}}\right)\end{array}$ & $\begin{array}{c}\Delta \boldsymbol{S}^{\mathbf{0}} \\
\left(\mathbf{c a l ~ m o l}^{-\mathbf{1}} \mathbf{~ d e g}^{-\mathbf{1}}\right)\end{array}$ & $\begin{array}{c}\Delta G^{\mathbf{0}} \\
\left(\mathbf{c a l ~ m o l}^{-\mathbf{1}}\right)\end{array}$ \\
\hline 2.05 & $\begin{array}{c}2.51 \times 10^{4} \\
\left( \pm 6.9 \times 10^{3}\right)\end{array}$ & $\begin{array}{c}-9.08 \times 10^{4} \\
\left( \pm 3.17 \times 10^{3}\right)\end{array}$ & -285 & $-5.95 \times 10^{3}$ \\
\hline
\end{tabular}

The heat profile of the mutant $G$ protein was exothermic with a negative heat pulse, indicating the protein-HS binding pattern. The changes in enthalpy $\left(\Delta H^{0}\right)$ and the Gibbs free energy $\left(\Delta G^{0}\right)$ were largely negative, which suggested the spontaneous nature of the reaction. The negative values of $\Delta G^{0}$ and $\Delta H^{0}$ showed that the binding of HS with the protein was mainly driven by the electrostatic interaction. The binding affinity $\left(K_{a}\right)$ value of HS with the mutant G protein was found to be $2.51 \times 10^{4} \mathrm{M}^{-1}$. However, in our previous investigation, we found a higher binding affinity with the wild-type $G$ protein; i.e., $10.7 \times 10^{4} \mathrm{M}^{-1}$ [58]. From these observations, we concluded that after the substitution of lysine $(\mathrm{K})$ with alanine $(\mathrm{A})$ in the $\mathrm{CX} 3 \mathrm{C}$ motif of the $\mathrm{G}$ protein, a low binding value was observed. The low binding of the mutant $G$ protein with HS suggested that mutation in this region altered the binding interactions. This observation was consistent with our fluorescence quenching results, in which we also observed low binding. A previous study demonstrated that RSV bound to the corresponding chemokine receptor (CX3CR1) via the CX3C chemokine motif $\left({ }^{182} \mathrm{CWAIC}{ }^{186}\right)$ of the $\mathrm{G}$ protein, which contributes to disease pathogenesis [15]. A recent study also showed that mutation in the CX3C motif by insertion of alanine $\left(\mathrm{A}^{186}\right)$, mutating it to CX4C $\left({ }^{182}\right.$ CWAIAC $\left.{ }^{187}\right)$, which is known to block binding to 
the CX3CR1, might decrease disease and immune modulation associated with the G protein of RSV [37]. The results obtained from the ITC may help to explain the binding mechanism of the virion with the host cell.

We observed a significant difference between the thermodynamic parameters of fluorescence and ITC. It is well known that fluorescence measures only the local changes around the microenvironment of the fluorophore upon ligand binding, whereas on the other hand, ITC monitors the global changes in terms of heat released or absorbed during the breaking or formation of bonds upon ligand-protein interactions [59]. Variations in thermodynamic parameters derived from fluorescence and ITC have been seen in several other ligand-protein interaction studies [60-62].

\subsubsection{Molecular Docking}

Molecular docking of heparan sulfate with the mutant $G$ protein was performed to determine the binding energy, as well as to identify the specific amino acid residues involved in ligand binding and their intramolecular distances. The heparan sulfate occupied the binding site pocket of the mutant $G$ protein and formed a single hydrogen bond with Asn1127, Pro132, Thr133, Ser191, and Glu226, and triple hydrogen bonds with Thr134. In addition, HS also formed two carbon-hydrogen bonds with Pro132 and Arg196 (Figure 10A,C). The intramolecular distance between the ligand and protein was found to be in the range of $2.03 \AA$ to $2.77 \AA$ (Figure $10 \mathrm{~B}$ ). The HS showed a binding energy of $-6.4 \mathrm{kcal} / \mathrm{mol}$ with the mutant $\mathrm{G}$ protein. The binding constant $\left(K_{b}\right)$ value was calculated using the value of the binding energy, and was found to be $4.9 \times 10^{4} / \mathrm{mol}$. The binding parameters of HS with the mutant G protein are given in Table 4.

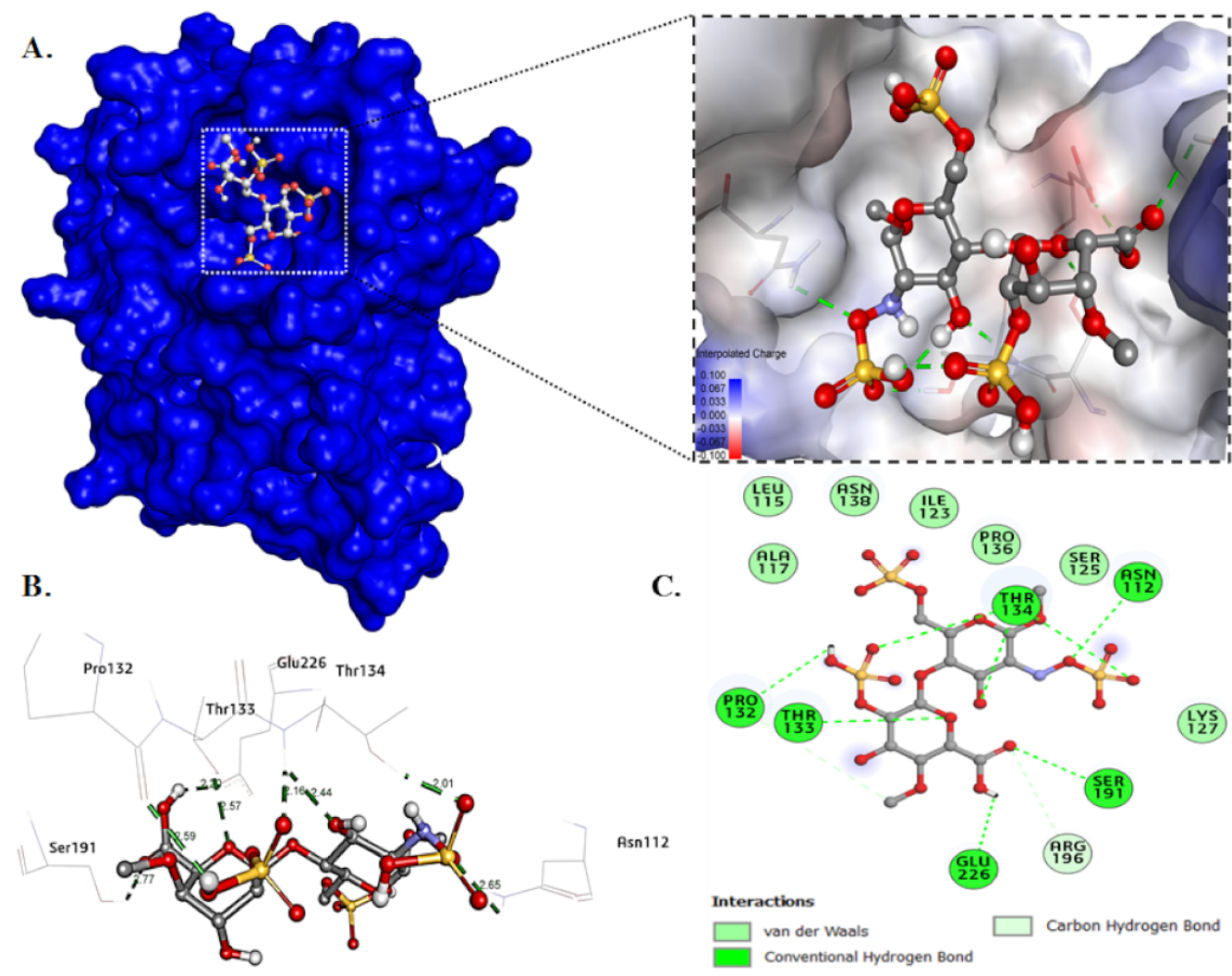

Figure 10. Molecular docking of mutant $G$ protein with heparan sulfate. (A) Surface view of docked protein-HS complex. (B) Illustration of the protein-HS complex showing hydrogen bond distances. (C) Detailed two-dimensional plot illustrating the type of interactions between protein and ligand. 
Table 4. Binding parameters of heparan sulfate with mutant $G$ protein obtained from fluorescence, ITC, and molecular docking.

\begin{tabular}{cccccc}
\hline \multirow{2}{*}{ Compound } & \multicolumn{2}{c}{ Fluorescence } & \multicolumn{2}{c}{ Docking } \\
\cline { 2 - 6 } & $\begin{array}{c}\text { Binding Constant } \\
(\boldsymbol{K}) \mathbf{M}^{-\mathbf{1}}\end{array}$ & $\begin{array}{c}\text { Binding Constant } \\
\left(\boldsymbol{K}_{\boldsymbol{a}}\right) \mathbf{M}^{-\mathbf{1}}\end{array}$ & $\begin{array}{c}\text { Binding Energy } \\
\left(\boldsymbol{\Delta} \boldsymbol{G}^{\mathbf{0}}\right) \mathbf{~ c a l ~} \mathbf{~ m o l}^{\mathbf{1}}\end{array}$ & $\begin{array}{c}\text { Binding Constant } \\
\boldsymbol{K}_{\boldsymbol{b}}(/ \mathbf{m o l})\end{array}$ & $\begin{array}{c}\text { Binding Energy } \\
(\boldsymbol{\Delta} \boldsymbol{G}) \mathbf{k c a l} / \mathbf{m o l}\end{array}$ \\
\hline Heparan sulfate & $2.08 \times 10^{5}$ & $2.51 \times 10^{4}$ & $-5.95 \times 10^{3}$ & $4.9 \times 10^{4}$ & -6.4 \\
\hline
\end{tabular}

However, in our previous investigation, the wild-type G-protein binding energy was $-6.8 \mathrm{kcal} / \mathrm{mol}$, and the key interacting residues Cys116, Lys117, and Arg196 were mainly involved in a binding interaction [45]. From these observations, we found that when we substituted the lysine residue with alanine (K117A) in the CX3C motif of the G protein, a low binding energy was found. The low binding of the mutant (K117A) G protein with HS was attributed to that mutation in this region disrupting the binding interactions. It was interesting to note that when we mutated the lysine to alanine, it did not form any hydrogen bond with Ala117. However, in the wild-type G protein, HS directly formed a hydrogen bond with Lys117. From the binding study, we also found that the mutated $\mathrm{G}$ protein did not form any carbon-hydrogen bond with Leu115 and Cys116, which were present in the wild-type $G$ protein. From these observations, we concluded that besides Lys117, Leu115 and Cys116 might also play an important role in the binding of the wild-type G protein that was absent in the mutant (K117A) protein.

Since we used only the ectodomain part of the $G$ protein for our study, the mutated amino acid position in the CX3C motif was K117A. However, the mutated amino acid position with respect to the full-length $G$ protein was K183A. Previously, Verga and colleagues created a synthetic peptide with alanine mutation at all positions from Ile183 to Lys195, and their study showed that Ile185 and Arg188 were very important in the recognition of lung mononuclear cells from BALB/c mice that were immunized by the RSV G protein [63]. In another study, Huang and colleagues showed that amino acids Arg188 and Lys192 were very important in providing protective immunity against RSV, as well as in induction of RSV-associated eosinophilia in BALB/c mice [64].

The binding of HS with the mutant protein determined by ITC and fluorescence measurements further complemented our molecular docking results. All the binding studies suggested that the substitution of lysine with alanine in the CX3C motif of G protein effectively inhibited the interaction with HS. The binding parameters of the mutant $G$ protein with HS obtained from fluorescence quenching, ITC, and molecular docking are given in Table 4.

Here, we propose that instead of the wild type, the mutant $G$ protein may be used for vaccine development, because the mutant protein may not bind to HS effectively. The binding parameters of the wild-type and mutant $\mathrm{G}$ proteins with HS are given in Table 5 . It must be noted that there was no shift in the fluorescence intensity of the mutant and wild-type proteins at physiological $\mathrm{pH}$. Hence, we assumed that the mutation in the $\mathrm{CX} 3 \mathrm{C}$ motif of $\mathrm{G}$ protein reduced the binding without affecting its tertiary structure.

Table 5. Comparative binding parameters of heparan sulfate with wild-type and mutant $\mathrm{G}$ proteins obtained from fluorescence, ITC, and molecular docking.

\begin{tabular}{ccccc}
\hline Compound & Proteins & $\begin{array}{c}\text { Binding Constant }(K) \\
\mathbf{M}^{-\mathbf{1}} \text { (Fluorescence) }\end{array}$ & $\begin{array}{c}\text { Binding Constant }\left(K_{a}\right) \\
\mathbf{M}^{-1}(\mathrm{ITC})\end{array}$ & $\begin{array}{c}\text { Binding Energy }(\Delta G) \\
\text { kcal/mol (Docking) }\end{array}$ \\
\hline \multirow{2}{*}{ Heparan sulfate } & Wild type G protein & $3.98 \times 10^{6}[45]$ & $10.7 \times 10^{4}[58]$ & $-6.8[45]$ \\
\cline { 2 - 6 } & Mutant G protein & $2.08 \times 10^{5}$ & $2.51 \times 10^{4}$ & -6.4 \\
\hline
\end{tabular}

\section{Materials and Methods}

\subsection{Materials}

Sodium chloride, imidazole, $\mathrm{GdmCl}$, urea, glycine, ethanol, Tris buffer, etc. were brought from Merck (Darmstadt, Germany). Glycerol, N-lauroylsarcosine, and Triton X-100 
were purchased from Sigma (St. Louis, MI, USA). Luria-Bertani broth, kanamycin, and imidazole were brought from Himedia, India. All the chemicals used for the experiments were of analytical grade.

\subsection{Cloning, Expression and Purification of Mutant G Protein}

The full-length G-protein gene sequence (accession no. KJ690590) was taken from the NCBI database. For our study, only the ectodomain part of the G protein was taken. The ectodomain region of the G-protein gene with a mutation in the CX3C motif (K117A) was codon-optimized and inserted in the pUC57 vector by commercial services (Gene Script, Piscataway, NJ, USA). The gene was further subcloned in the pET28a expression vector. The recombinant expression vector was transformed into the E. coli (DH5 $\alpha)$ strain, and the plasmid was isolated using a commercially available plasmid isolation kit and analyzed through agarose gel electrophoresis. The plasmid was further transformed and expressed into the E. coli strain of BL23 (DE3), and the protein was purified using Ni-NTA affinity chromatography with some changes described previously $[58,65,66]$. Briefly, the protein was expressed at $30{ }^{\circ} \mathrm{C}$ for $12 \mathrm{~h}$ with induction of $0.5 \mathrm{mM}$ IPTG. The inclusion bodies (IBs) were prepared using a standard protocol [58] and solubilized in buffer (50 mM CAPS buffer $\mathrm{pH} 11.0,100 \mathrm{mM} \mathrm{NaCl}$, and $0.5 \% \mathrm{~N}$-lauroylsarcosine), and the protein was purified by $\mathrm{Ni}$ NTA affinity chromatography. The desired protein fraction was eluted with an increasing concentration of imidazole. The fractions of eluted protein were analyzed through sodium dodecyl sulphate polyacrylamide gel electrophoresis (SDS-PAGE). The desired eluted sample was dialyzed against $\mathrm{NaCl}(100 \mathrm{mM})$ and Tris buffer $(20 \mathrm{mM})$ at $\mathrm{pH} 7.5$. The buffer was repeatedly changed at least 5 times in $24 \mathrm{~h}$ at $4{ }^{\circ} \mathrm{C}$ to obtain the refolded protein. The concentration of protein was measured by a molar absorbance coefficient $(\varepsilon)$ of $8730 \mathrm{M}^{-1} \mathrm{~cm}^{-1}$ at $280 \mathrm{~nm}$ using Jasco V-600 UV-visible spectrophotometer [67].

\subsection{Sample Preparation}

A wide range of buffers was used to determine the $\mathrm{pH}$-dependent alteration in the

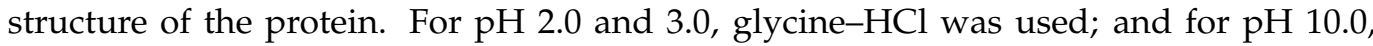
11.0, and 12.0, glycine-NaOH buffer was prepared. For $\mathrm{pH} 4.0$ and 5.0, acetate buffer was prepared. For pH 6.0 and 7.0, phosphate buffer was prepared. For pH 8.0 and 9.0, Tris buffer was prepared. Before performing the spectral measurements, the sample was incubated for at least 2-3 h to attain equilibrium. A stock solution of $\mathrm{GdmCl}(8.7 \mathrm{M})$ and urea $(10.5 \mathrm{M})$ was prepared to observe the structural stability of the protein. The stock solution of urea and $\mathrm{GdmCl}$ was prepared in $25 \mathrm{mM}$ Tris buffer at $\mathrm{pH}$ 8.0. The calculated amount of buffer, protein, and denaturant (urea/GdmCl) was mixed and incubated for 3-4 $\mathrm{h}$ at room temperature to ensure the completion of the denaturation process. All the experiments were performed in triplicate, and the blank values were subtracted from each measurement of the samples.

\subsection{Fluorescence Measurements}

The fluorescence emission spectra of the mutant protein were recorded in a Jasco spectrofluorometer (FP6200) with a quartz cuvette of $1 \mathrm{~cm}$ path length at $25 \pm 1{ }^{\circ} \mathrm{C}$. We observed alterations in the emission spectra of the mutant $G$ protein in a wide range of buffers ( $\mathrm{pH}$ 2.0-12.0) and different concentrations of urea and $\mathrm{GdmCl}$. For spectral measurements, the entrance and exit slit widths were set at $5 \mathrm{~nm}$ and $10 \mathrm{~nm}$, respectively. The protein sample was excited at $280 \mathrm{~nm}$, and we collected the emission spectra in the wavelength region of 300-400 $\mathrm{nm}$.

\subsection{ANS Measurements}

The ANS fluorescence was performed with a Jasco spectrofluorometer (FP6200) having a quartz cuvette of $1.0 \mathrm{~cm}$ path length at $25 \pm 1^{\circ} \mathrm{C}$. For ANS fluorescence measurements, the protein-to-ANS ratio was taken at 1:20. For spectral measurements, the excitation and emission slit widths were set at $5 \mathrm{~nm}$. The ANS sample was excited at $380 \mathrm{~nm}$, and we 
collected the spectra in the wavelength range of 400-600 $\mathrm{nm}$. Before performing the spectral measurements, the prepared samples were incubated at least for $30 \mathrm{~min}$ in the dark.

\subsection{Denaturation Spectral Measurements}

The transition curves generated after plotting the spectral property $y\left(F_{344}\right)$ against the molar concentration of $\mathrm{GdmCl} /$ urea were evaluated for the determination of protein stability. Thermodynamic properties such as $m$ and $C_{m}$ were used to calculate the stability of the protein, where $\Delta G_{D}{ }^{0}$ is the Gibbs free energy change in the absence of denaturants, $m$ is the slope $\left(\partial \Delta G_{D} / \partial[G d m C l /\right.$ urea $]$, and $C_{m}\left(=\Delta G_{D}{ }^{0} / m\right)$ is the transition midpoint of the denaturation curve where $\Delta G_{D}=0$. Least-square approaches were used to fit the denaturation transition curve by the following equation:

$$
y=\frac{y_{N}+y_{D} \times \operatorname{Exp}\left[-\left(\Delta G_{D}^{0}-m[\text { urea } / G d m C l]\right) / R T\right]}{\left(1+\operatorname{Exp}\left[-\left(\Delta G_{D}^{0}-m[\text { urea } / G d m C l]\right) / R T\right]\right)}
$$

where $y_{N}$ and $y_{D}$ represent the anticipated optical properties of the native and denatured protein, respectively, under the same experimental condition in which $y$ was recorded; $R$ represents the universal gas constant; and $T$ represents the temperature in Kelvin.

\subsection{Fluorescence Binding Measurements}

The fluorescence binding studies of heparan sulfate with the mutant $G$ protein were performed by a Jasco spectrofluorometer (FP6200) with a quartz cuvette of $1 \mathrm{~cm}$ path length at $25 \pm 1{ }^{\circ} \mathrm{C}$. The stock solution of HS was prepared in $20 \mathrm{mM}$ Tris buffer ( $\mathrm{pH}$ 7.5). An increasing concentration of HS $(2-40 \mu \mathrm{M})$ was used to titrate against the constant concentration of the protein. The protein sample was excited at $280 \mathrm{~nm}$, and we collected the spectra at 300-400 nm. For spectral measurements, the entrance and exit slit widths were set at $5 \mathrm{~nm}$ and $10 \mathrm{~nm}$, respectively. The blank spectra (buffer and HS) were subtracted from the titrated samples to obtain the final spectra of the protein.

The fluorescence binding of HS with mutant G protein was examined to determine the values of the number of binding sites $(n)$, Stern-Volmer constant $\left(K_{s v}\right)$, and binding constant $(K)$.

Equation (2) was used to find the Stern-Volmer constant by analyzing the quenching data:

$$
\frac{F_{0}}{F}=1+K_{S V}[C]
$$

where $F_{0}$ represents the protein intensity in the absence of HS, $F$ represents the protein intensity at a particular concentration of heparan sulfate at $344 \mathrm{~nm},[C]$ represents the various concentrations of HS, and $K_{S V}$ represents the Stern-Volmer binding constant.

Equation (3) was used to determine the bimolecular quenching constant $\left(K_{q}\right)$ to check the mode of quenching in the protein-ligand complex:

$$
K_{q}=\frac{K_{S V}}{\tau_{o}}
$$

where $\tau_{0}$ is the average integral fluorescence lifetime of tryptophan $\left(2.7 \times 10^{-9} \mathrm{~s}\right)$.

Further, Equation (4) was used to determine the modified Stern-Volmer constant (double $\log$ plot) that gave the value of the binding constant $(K)$ in the protein-ligand complex:

$$
\log \left(\frac{F_{0}-F}{F}\right)=\log K+n
$$

where $n$ represents the number of binding sites, and $K$ represents the binding constant of the protein-ligand complex. 


\subsection{Absorbance Binding Measurements}

The spectral measurement of heparan sulfate with the mutant $G$ protein was performed with a Jasco UV/visible spectrophotometer (V-660) using $1 \mathrm{~cm}$ path length cuvettes. A constant concentration of protein was titrated with an increasing concentration of heparan sulfate $(2-56 \mu \mathrm{M})$, and we collected the spectra in the wavelength range of $240-340 \mathrm{~nm}$.

\subsection{ITC Measurements}

The binding studies of the heparan sulfate with the mutant $G$ protein were also performed by isothermal titration calorimetry at $25^{\circ} \mathrm{C}$ using VP-ITC (MicroCal, Northampton, MA, USA). The sample cell was injected at a 1:20 ratio with $10 \mu \mathrm{M}$ protein and $200 \mu \mathrm{M}$ heparan sulfate for titration. The $10 \mu \mathrm{L}$ aliquots of HS were loaded in every step at an interval of $300 \mathrm{~s}$ from the syringe. The stoichiometry value $(n)$, binding constant $\left(K_{a}\right)$, enthalpy change $\left(\Delta H^{0}\right)$, and entropy change $\left(\Delta S^{0}\right)$ were determined from the measured heat change $(\delta H i)$ upon the interaction of the protein with heparan sulfate. The obtained raw data were accessed and analyzed using MicroCal Origin 8.0 software (MicroCal, Northampton, MA, USA). Using Equation (5), we calculated the Gibbs free energy change $\left(\Delta G^{0}\right)$ using the thermodynamic parameters obtained above:

$$
\Delta G^{0}=-R T \ln K_{a}=\Delta H-T \Delta S
$$

\subsection{Molecular Docking}

The docking studies were performed to determine the interaction of heparan sulfate with the mutant $G$ protein. The crystal structure of the $G$ protein has yet to be determined. Hence, for the docking study, we modeled the three-dimensional structure of the ectodomain $\mathrm{G}$ protein using in silico methods. In our earlier studies, we described the modeled structure of the protein in detail [68]. The point mutation was generated in the CX3C motif of the ectodomain $G$ protein at position 117 by substituting the lysine residue with alanine (K117A) using PyMOL software. Heparan sulfate's chemical structure was retrieved from the PubChem database and converted into a PDBQT file using the Open Babel application of PyRx. Docking and visualization were carried out using bioinformatics tools such as PyRx (accessed on 15 December 2021), PyMOL (Schrödinger, Inc., New York, NY, USA, 2010) and Discovery studio software (Dassault Systèmes BIOVIA, San Diego, CA, USA, 2017) [69,70]. The docking was performed by forming the grid box in such a way as to occupy the active binding site of the protein. The docking study was performed structurally blind, which meant that the molecule was free to move around and search the binding sites of the protein with the most favorable and minimum energy conformation. Based on the binding energy, the best docked structure was taken and analyzed using Discovery studio software. The binding constant $\left(K_{b}\right)$ value for the ligand-protein interaction was calculated using Equation (6):

$$
\Delta G=-R T \ln K_{b}
$$

where $R$ is the gas constant $(1.98719 \mathrm{cal} / \mathrm{mol}), T$ is the temperature in Kelvin $(298.15 \mathrm{~K})$, and $\Delta G$ is the docking energy.

\section{Conclusions}

In conclusion, this study demonstrated that a mutation in the CX3C motif of the $G$ protein disrupted the binding of heparan sulfate with the mutant protein as compared to the wild-type $G$ protein. The obtained experimental results demonstrated that targeting the mutation in the $G$ protein may be an effective strategy to counteract the inhibition of host-pathogen interaction. For the development of an effective and safer vaccine, this type of amino acid mutagenesis may be exploited to improve vaccine efficacy. The mutation in the $\mathrm{CX} 3 \mathrm{C}$ motif of the $\mathrm{G}$ protein may be used as a platform to develop an effective and safer vaccine against RSV. 


\begin{abstract}
Author Contributions: S.P. and A.I. supervised and designed the experimental work and prepared the final draft of the manuscript; A.H. had performed all experiments and prepared the first draft of the manuscript; Z.A.P. performed the ITC experiment; A.S., S.A., T.H. and F.N.A. provided writing assistance and language help. S.P., A.I. and A.A. proofread the article. All authors have read and agreed to the published version of the manuscript.
\end{abstract}

Funding: This research work was supported by a grant funded by the Council of Scientific and Industrial Research, India (37(1697)17/EMR-II). The other research work in our laboratory is also supported by Central Council for Research in Unani Medicine, India (F.No.3-63/2019-CCRUM/Tech). The authors also acknowledge the generous support from the Deanship of Scientific Research at King Saud University, Riyadh (Grant No. RG-1439-74).

Institutional Review Board Statement: Not applicable.

Data Availability Statement: Not applicable.

Acknowledgments: A.H. thanks the Indian Council of Medical Research for the award of a senior research fellowship (VIR/Fellowship/5/2018-ECD-I). S.P and A.I. also thank the FIST program (SR/FST/LSI-541/2012) funded by Department of Science and Technology, India for providing equipment for research work.

Conflicts of Interest: The authors declare no conflict of interest.

\title{
References
}

1. Adams, M.J.; Lefkowitz, E.J.; King, A.M.Q.; Harrach, B.; Harrison, R.L.; Knowles, N.J.; Kropinski, A.M.; Krupovic, M.; Kuhn, J.H.; Mushegian, A.R.; et al. Ratification vote on taxonomic proposals to the International Committee on Taxonomy of Viruses. Arch. Virol. 2016, 161, 2921-2949. [CrossRef] [PubMed]

2. Chatzis, O.; Darbre, S.; Pasquier, J.; Meylan, P.; Manuel, O.; Aubert, J.D.; Beck-Popovic, M.; Masouridi-Levrat, S.; Ansari, M.; Kaiser, L.; et al. Burden of severe RSV disease among immunocompromised children and adults: A 10 year retrospective study. BMC Infect. Dis. 2018, 18, 111. [CrossRef] [PubMed]

3. Coultas, J.A.; Smyth, R.; Openshaw, P.J. Respiratory syncytial virus (RSV): A scourge from infancy to old age. Thorax 2019, 74, 986-993. [CrossRef] [PubMed]

4. Stein, R.; Bont, L.J.; Zar, H.; Polack, F.P.; Park, C.; Claxton, A.; Borok, G.; Butylkova, Y.; Wegzyn, C. Respiratory syncytial virus hospitalization and mortality: Systematic review and meta-analysis. Pediatr. Pulmonol. 2016, 52, 556-569. [CrossRef] [PubMed]

5. Shi, T.; McAllister, D.A.; O’Brien, K.L.; Simoes, E.A.F.; Madhi, S.A.; Gessner, B.D.; Polack, F.P.; Balsells, E.; Acacio, S.; Aguayo, C.; et al. Global, regional, and national disease burden estimates of acute lower respiratory infections due to respiratory syncytial virus in young children in 2015: A systematic review and modelling study. Lancet 2017, 390, 946-958. [CrossRef]

6. Connor, E.M. Palivizumab, a Humanized Respiratory Syncytial Virus Monoclonal Antibody, Reduces Hospitalization From Respiratory Syncytial Virus Infection in High-risk Infants. Pediatrics 1998, 102, 531-537. [CrossRef]

7. McLellan, J.; Ray, W.C.; Peeples, M.E. Structure and Function of Respiratory Syncytial Virus Surface Glycoproteins. Curr. Top. Microbiol. Immunol. 2013, 372, 83-104. [CrossRef] [PubMed]

8. $\quad$ Langedijk, J.P.M.; Schaaper, W.M.M.; Meloen, R.H.; Van Oirschot, J.T. Proposed three-dimensional model for the attachment protein G of respiratory syncytial virus. J. Gen. Virol. 1996, 77, 1249-1257. [CrossRef]

9. Melero, J.A.; Mas, V.; McLellan, J.S. Structural, antigenic and immunogenic features of respiratory syncytial virus glycoproteins relevant for vaccine development. Vaccine 2016, 35, 461-468. [CrossRef]

10. Teng, M.N.; Collins, P.L. The Central Conserved Cystine Noose of the Attachment G Protein of Human Respiratory Syncytial Virus Is Not Required for Efficient Viral Infection In Vitro or In Vivo. J. Virol. 2002, 76, 6164-6171. [CrossRef]

11. Johnson, P.R.; Spriggs, M.K.; Olmsted, R.A.; Collins, P.L. The G glycoprotein of human respiratory syncytial viruses of subgroups A and B: Extensive sequence divergence between antigenically related proteins. Proc. Natl. Acad. Sci. USA 1987, 84, 5625-5629. [CrossRef]

12. Kauvar, L.M.; Harcourt, J.L.; Haynes, L.M.; Tripp, R.A. Therapeutic targeting of respiratory syncytial virus G-protein. Immunotherapy 2010, 2, 655-661. [CrossRef]

13. Gorman, J.J.; Ferguson, B.L.; Speelman, D.; Mills, J. Determination of the disulfide bond arrangement of human respiratory syncytial virus attachment $(\mathrm{G})$ protein by matrix-assisted laser desorption/ionization time-of-flight mass spectrometry. Protein Sci. 1997, 6, 1308-1315. [CrossRef]

14. Wertz, G.W.; Collins, P.L.; Huang, Y.; Gruber, C.; Levine, S.; Ball, L.A. Nucleotide sequence of the G protein gene of human respiratory syncytial virus reveals an unusual type of viral membrane protein. Proc. Natl. Acad. Sci. USA 1985, 82, 4075-4079. [CrossRef]

15. Chirkova, T.; Lin, S.; Oomens, A.G.P.; Gaston, K.A.; Boyoglu-Barnum, S.; Meng, J.; Stobart, C.; Cotton, C.U.; Hartert, T.V.; Moore, M.L.; et al. CX3CR1 is an important surface molecule for respiratory syncytial virus infection in human airway epithelial cells. J. Gen. Virol. 2015, 96, 2543-2556. [CrossRef] 
16. Johnson, S.M.; McNally, B.A.; Ioannidis, I.; Flano, E.; Teng, M.N.; Oomens, A.G.; Walsh, E.E.; Peeples, M.E. Respiratory Syncytial Virus Uses CX3CR1 as a Receptor on Primary Human Airway Epithelial Cultures. PLoS Pathog. 2015, 11, e1005318. [CrossRef]

17. Langedijk, J.P.; de Groot, L.; Berendsen, H.J.; van Oirschot, J.T. Structural Homology of the Central Conserved Region of the Attachment Protein G of Respiratory Syncytial Virus with the Fourth Subdomain of 55-kDa Tumor Necrosis Factor Receptor. Virology 1998, 243, 293-302. [CrossRef]

18. Tripp, R.A.; Jones, L.P.; Haynes, L.M.; Zheng, H.; Murphy, P.M.; Anderson, L.J. CX3C chemokine mimicry by respiratory syncytial virus G glycoprotein. Nat. Immunol. 2001, 2, 732-738. [CrossRef]

19. Feldman, S.A.; Hendry, R.M.; Beeler, J.A. Identification of a Linear Heparin Binding Domain for Human Respiratory Syncytial Virus Attachment Glycoprotein G. J. Virol. 1999, 73, 6610-6617. [CrossRef]

20. Hallak, L.K.; Spillmann, D.; Collins, P.L.; Peeples, M.E. Glycosaminoglycan Sulfation Requirements for Respiratory Syncytial Virus Infection. J. Virol. 2000, 74, 10508-10513. [CrossRef]

21. Escribano-Romero, E.; Rawling, J.; Garciía-Barreno, B.; Melero, J.A. The Soluble Form of Human Respiratory Syncytial Virus Attachment Protein Differs from the Membrane-Bound Form in Its Oligomeric State but Is Still Capable of Binding to Cell Surface Proteoglycans. J. Virol. 2004, 78, 3524-3532. [CrossRef]

22. Zhivaki, D.; Lemoine, S.; Lim, A.; Morva, A.; Vidalain, P.-O.; Schandene, L.; Casartelli, N.; Rameix-Welti, M.-A.; Hervé, P.-L.; Dériaud, E.; et al. Respiratory Syncytial Virus Infects Regulatory B Cells in Human Neonates via Chemokine Receptor CX3CR1 and Promotes Lung Disease Severity. Immunity 2017, 46, 301-314. [CrossRef]

23. Schmidt, M.E.; Varga, S.M. Modulation of the host immune response by respiratory syncytial virus proteins. J. Microbiol. 2017, 55, 161-171. [CrossRef]

24. Bakre, A.A.; Harcourt, J.L.; Haynes, L.M.; Anderson, L.J.; Tripp, R.A. The Central Conserved Region (CCR) of Respiratory Syncytial Virus (RSV) G Protein Modulates Host miRNA Expression and Alters the Cellular Response to Infection. Vaccines 2017, 5, 16. [CrossRef]

25. Boyoglu-Barnum, S.; Gaston, K.A.; Todd, S.O.; Boyoglu, C.; Chirkova, T.; Barnum, T.R.; Jorquera, P.; Haynes, L.M.; Tripp, R.A.; Moore, M.L.; et al. A Respiratory Syncytial Virus (RSV) Anti-G Protein F(ab') 2 Monoclonal Antibody Suppresses Mucous Production and Breathing Effort in RSV rA2-line19F-Infected BALB/c Mice. J. Virol. 2013, 87, 10955-10967. [CrossRef]

26. Lee, H.-J.; Lee, J.-Y.; Park, M.-H.; Kim, J.; Chang, J. Monoclonal Antibody against G Glycoprotein Increases Respiratory Syncytial Virus Clearance In Vivo and Prevents Vaccine-Enhanced Diseases. PLoS ONE 2017, 12, e0169139. [CrossRef]

27. Caidi, H.; Miao, C.; Thornburg, N.J.; Tripp, R.A.; Anderson, L.J.; Haynes, L.M. Anti-respiratory syncytial virus (RSV) G monoclonal antibodies reduce lung inflammation and viral lung titers when delivered therapeutically in a BALB/c mouse model. Antivir. Res. 2018, 154, 149-157. [CrossRef]

28. Boyoglu-Barnum, S.; Chirkova, T.; Todd, S.O.; Barnum, T.R.; Gaston, K.A.; Jorquera, P.; Haynes, L.M.; Tripp, R.A.; Moore, M.L.; Anderson, L.J. Prophylaxis with a Respiratory Syncytial Virus (RSV) Anti-G Protein Monoclonal Antibody Shifts the Adaptive Immune Response to RSV rA2-line19F Infection from Th2 to Th1 in BALB/c Mice. J. Virol. 2014, 88, 10569-10583. [CrossRef]

29. Boyoglu-Barnum, S.; Todd, S.O.; Chirkova, T.; Barnum, T.R.; Gaston, K.A.; Haynes, L.M.; Tripp, R.A.; Moore, M.L.; Anderson, L.J. An anti-G protein monoclonal antibody treats RSV disease more effectively than an anti-F monoclonal antibody in BALB/c mice. Virology 2015, 483, 117-125. [CrossRef]

30. Cortjens, B.; Yasuda, E.; Yu, X.; Wagner, K.; Claassen, Y.B.; Bakker, A.Q.; van Woensel, J.B.M.; Beaumont, T. Broadly Reactive AntiRespiratory Syncytial Virus G Antibodies from Exposed Individuals Effectively Inhibit Infection of Primary Airway Epithelial Cells. J. Virol. 2017, 91, e02357-16. [CrossRef]

31. Han, J.; Takeda, K.; Wang, M.; Zeng, W.; Jia, Y.; Shiraishi, Y.; Okamoto, M.; Dakhama, A.; Gelfand, E.W. Effects of Anti-G and Anti-F Antibodies on Airway Function after Respiratory Syncytial Virus Infection. Am. J. Respir. Cell Mol. Biol. 2014, 51, 143-154. [CrossRef] [PubMed]

32. Collarini, E.J.; Lee, F.E.-H.; Foord, O.; Park, M.; Sperinde, G.; Wu, H.; Harriman, W.D.; Carroll, S.F.; Ellsworth, S.L.; Anderson, L.J.; et al Potent High-Affinity Antibodies for Treatment and Prophylaxis of Respiratory Syncytial Virus Derived from B Cells of Infected Patients. J. Immunol. 2009, 183, 6338-6345. [CrossRef] [PubMed]

33. Nguyen, T.N.; Power, U.; Robert, A.; Haeuw, J.-F.; Helffer, K.; Perez, A.; Asin, M.-A.; Corvaia, N.; Libon, C. The Respiratory Syncytial Virus G Protein Conserved Domain Induces a Persistent and Protective Antibody Response in Rodents. PLoS ONE 2012, 7, e34331. [CrossRef] [PubMed]

34. Choi, Y.; Mason, C.S.; Jones, L.P.; Crabtree, J.; Jorquera, P.A.; Tripp, R.A. Antibodies to the Central Conserved Region of Respiratory Syncytial Virus (RSV) G Protein Block RSV G Protein CX3C-CX3CR1 Binding and Cross-Neutralize RSV A and B Strains. Viral Immunol. 2012, 25, 193-203. [CrossRef]

35. Sparer, T.; Matthews, S.; Hussell, T.; Rae, A.J.; Garcia-Barreno, B.; Melero, J.A.; Openshaw, P.J. Eliminating a Region of Respiratory Syncytial Virus Attachment Protein Allows Induction of Protective Immunity without Vaccine-enhanced Lung Eosinophilia. J. Exp. Med. 1998, 187, 1921-1926. [CrossRef]

36. Tebbey, P.W.; Hagen, M.; Hancock, G.E. Atypical Pulmonary Eosinophilia Is Mediated by a Specific Amino Acid Sequence of the Attachment (G) Protein of Respiratory Syncytial Virus. J. Exp. Med. 1998, 188, 1967-1972. [CrossRef]

37. Boyoglu-Barnum, S.; Todd, S.O.; Meng, J.; Barnum, T.R.; Chirkova, T.; Haynes, L.M.; Jadhao, S.J.; Tripp, R.A.; Oomens, A.G.; Moore, M.L.; et al. Mutating the CX3C Motif in the G Protein Should Make a Live Respiratory Syncytial Virus Vaccine Safer and More Effective. J. Virol. 2017, 91, e02059-16. [CrossRef] 
38. Jorquera, P.A.; Oakley, K.E.; Powell, T.J.; Palath, N.; Boyd, J.G.; Tripp, R.A. Layer-By-Layer Nanoparticle Vaccines Carrying the G Protein CX3C Motif Protect against RSV Infection and Disease. Vaccines 2015, 3, 829-849. [CrossRef]

39. Zhang, W.; Choi, Y.; Haynes, L.M.; Harcourt, J.L.; Anderson, L.J.; Jones, L.P.; Tripp, R.A. Vaccination To Induce Antibodies Blocking the CX3C-CX3CR1 Interaction of Respiratory Syncytial Virus G Protein Reduces Pulmonary Inflammation and Virus Replication in Mice. J. Virol. 2010, 84, 1148-1157. [CrossRef]

40. Harcourt, J.L.; Karron, R.A.; Tripp, R.A. Anti-G Protein Antibody Responses to Respiratory Syncytial Virus Infection or Vaccination Are Associated with Inhibition of G Protein CX3C-CX3CR1 Binding and Leukocyte Chemotaxis. J. Infect. Dis. 2004, 190, 1936-1940. [CrossRef]

41. Bergeron, H.; Murray, J.; Castrejon, A.N.; DuBois, R.; Tripp, R. Respiratory Syncytial Virus (RSV) G Protein Vaccines with Central Conserved Domain Mutations Induce CX3C-CX3CR1 Blocking Antibodies. Viruses 2021, 13, 352. [CrossRef]

42. Dehaghani, S.A.; Babaeipour, V.; Mofid, M.R.; Divsalar, A.; Faraji, F. An efficient purification method for high recovery of Recombinant Human Granulocyte Colony Stimulating Factor from recombinant E. coli. Int. J. Environ. Sci. Dev. 2010, 111-114. [CrossRef]

43. Gasymov, O.K.; Abduragimov, A.R.; Glasgow, B.J. pH-Dependent Conformational Changes in Tear Lipocalin by Site-Directed Tryptophan Fluorescence. Biochemistry 2009, 49, 582-590. [CrossRef]

44. Alston, R.W.; Urbanikova, L.; Sevcik, J.; Lasagna, M.; Reinhart, G.D.; Scholtz, J.M.; Pace, C.N. Contribution of Single Tryptophan Residues to the Fluorescence and Stability of Ribonuclease Sa. Biophys. J. 2004, 87, 4036-4047. [CrossRef]

45. Hamza, A.; Samad, A.; Imam, A.; Faizan, I.; Ahmed, A.; Almajhdi, F.N.; Hussain, T.; Islam, A.; Parveen, S. Structural Characterization of Ectodomain G Protein of Respiratory Syncytial Virus and Its Interaction with Heparan Sulfate: Multi-Spectroscopic and In Silico Studies Elucidating Host-Pathogen Interactions. Molecules 2021, 26, 7398. [CrossRef]

46. Naiyer, A.; Hassan, I.; Islam, A.; Sundd, M.; Ahmad, F. Structural characterization of MG and pre-MG states of proteins by MD simulations, NMR, and other techniques. J. Biomol. Struct. Dyn. 2015, 33, 2267-2284. [CrossRef]

47. Gupta, P.; Khan, F.I.; Roy, S.; Anwar, S.; Dahiya, R.; Alajmi, M.F.; Hussain, A.; Rehman, M.T.; Lai, D.; Hassan, M.I. Functional implications of $\mathrm{pH}$-induced conformational changes in the Sphingosine kinase 1. Spectrochim. Acta Part A Mol. Biomol. Spectrosc. 2020, 225, 117453. [CrossRef]

48. Haque, A.; Ubaid-Ullah, S.; Zaidi, S.; Hassan, I.; Islam, A.; Batra, J.K.; Ahmad, F. Characterization of pre-molten globule state of yeast iso-1-cytochrome $\mathrm{c}$ and its deletants at $\mathrm{pH} 6.0$ and $25^{\circ} \mathrm{C}$. Int. J. Biol. Macromol. 2015, 72, 1406-1418. [CrossRef]

49. Khan, P.; Parkash, A.; Islam, A.; Hassan, I.; Ahmad, F. Molecular basis of the structural stability of hemochromatosis factor E: A combined molecular dynamic simulation and GdmCl-induced denaturation study. Biopolymers 2015, 105, 133-142. [CrossRef]

50. Idrees, D.; Prakash, A.; Haque, A.; Islam, A.; Ahmad, F.; Hassan, I. Spectroscopic and MD simulation studies on unfolding processes of mitochondrial carbonic anhydrase VA induced by urea. J. Biomol. Struct. Dyn. 2016, 34, 1987-1997. [CrossRef]

51. Royer, C.A. Probing Protein Folding and Conformational Transitions with Fluorescence. Chem. Rev. 2006, 106, 1769-1784. [CrossRef]

52. O’Brien, E.P.; Dima, R.I.; Brooks, B.; Thirumalai, D. Interactions between Hydrophobic and Ionic Solutes in Aqueous Guanidinium Chloride and Urea Solutions: Lessons for Protein Denaturation Mechanism. J. Am. Chem. Soc. 2007, 129, 7346-7353. [CrossRef]

53. Zangi, R.; Zhou, R.; Berne, B.J. Urea's Action on Hydrophobic Interactions. J. Am. Chem. Soc. 2009, 131, 1535-1541. [CrossRef]

54. Monera, O.D.; Kay, C.M.; Hodges, R.S. Protein denaturation with guanidine hydrochloride or urea provides a different estimate of stability depending on the contributions of electrostatic interactions. Protein Sci. 1994, 3, 1984-1991. [CrossRef]

55. Anwar, S.; Shamsi, A.; Shahbaaz, M.; Queen, A.; Khan, P.; Hasan, G.M.; Islam, A.; Alajmi, M.F.; Hussain, A.; Ahmad, F.; et al Rosmarinic Acid Exhibits Anticancer Effects via MARK4 Inhibition. Sci. Rep. 2020, 10, 10300. [CrossRef]

56. Prasad, S.; Mandal, I.; Singh, S.; Paul, A.; Mandal, B.; Venkatramani, R.; Swaminathan, R. Near UV-Visible electronic absorption originating from charged amino acids in a monomeric protein. Chem. Sci. 2017, 8, 5416-5433. [CrossRef]

57. Wang, H.-D.; Niu, C.H.; Yang, Q.; Badea, I. Study on protein conformation and adsorption behaviors in nanodiamond particle-Protein complexes. Nanotechnology 2011, 22, 145703. [CrossRef]

58. Hamza, A.; Shafat, Z.; Parray, Z.A.; Hisamuddin, M.; Khan, W.H.; Ahmed, A.; Almajhdi, F.N.; Farrag, M.A.; Mohammed, A.A.; Islam, A.; et al. Structural Characterization and Binding Studies of the Ectodomain G Protein of Respiratory Syncytial Virus Reveal the Crucial Role of $\mathrm{pH}$ with Possible Implications in Host-Pathogen Interactions. ACS Omega 2021, 6, 10403-10414. [CrossRef]

59. Zaidi, N.; Ajmal, M.R.; Rabbani, G.; Ahmad, E.; Khan, R.H. A Comprehensive Insight into Binding of Hippuric Acid to Human Serum Albumin: A Study to Uncover Its Impaired Elimination through Hemodialysis. PLoS ONE 2013, 8, e71422. [CrossRef]

60. Rehman, M.T.; Shamsi, H.; Khan, A.U. Insight into the Binding Mechanism of Imipenem to Human Serum Albumin by Spectroscopic and Computational Approaches. Mol. Pharm. 2014, 11, 1785-1797. [CrossRef]

61. Keswani, N.; Choudhary, S.; Kishore, N. Interaction of weakly bound antibiotics neomycin and lincomycin with bovine and human serum albumin: Biophysical approach. J. Biochem. 2010, 148, 71-84. [CrossRef] [PubMed]

62. Roy, S.; Mohammad, T.; Gupta, P.; Dahiya, R.; Parveen, S.; Luqman, S.; Hasan, G.M.; Hassan, I. Discovery of Harmaline as a Potent Inhibitor of Sphingosine Kinase-1: A Chemopreventive Role in Lung Cancer. ACS Omega 2020, 5, 21550-21560. [CrossRef] [PubMed] 
63. Varga, S.; Wissinger, E.L.; Braciale, T.J. The Attachment (G) Glycoprotein of Respiratory Syncytial Virus Contains a Single Immunodominant Epitope That Elicits Both Th1 and Th2 CD4+T Cell Responses. J. Immunol. 2000, 165, 6487-6495. [CrossRef] [PubMed]

64. Huang, Y.; Anderson, R. A single amino acid substitution in a recombinant G protein vaccine drastically curtails protective immunity against respiratory syncytial virus (RSV). Vaccine 2003, 21, 2500-2505. [CrossRef]

65. Shafat, Z.; Hamza, A.; Deeba, F.; Faizan, I.; Khan, N.; Islam, A.; Ahmed, A.; Alamery, S.F.; Parveen, S. Optimization of parameters for expression and purification of G glycoprotein ectodomain of respiratory syncytial virus. Future Virol. 2020, 15, $223-233$. [CrossRef]

66. Khan, W.H.; Srungaram, V.L.N.R.; Islam, A.; Beg, I.; Haider, S.H.; Ahmad, F.; Broor, S.; Parveen, S. Biophysical characterization of $\mathrm{G}$ protein ectodomain of group B human respiratory syncytial virus fromE. coli. Prep. Biochem. Biotechnol. 2015, 46, 483-488. [CrossRef]

67. Pace, C.N.; Vajdos, F.; Fee, L.; Grimsley, G.; Gray, T. How to measure and predict the molar absorption coefficient of a protein. Protein Sci. 1995, 4, 2411-2423. [CrossRef]

68. Shafat, Z.; Faizan, I.; Tazeen, A.; Farooqui, A.; Deeba, F.; Aftab, S.; Hamza, A.; Parveen, S.; Islam, A.; Broor, S.; et al. In-silico analysis of ectodomain G protein of Respiratory Syncytial Virus. Indian J. Health Sci. Care 2017, 4, 110. [CrossRef]

69. The PyMOL Molecular Graphics System; Version 1; Schrödinger, Inc.: New York, NY, USA, 2010.

70. Discovery Studio Software; Dassault Systèmes BIOVIA: San Diego, CA, USA, 2017. 